Revista

Actualidades Investigativas

en Educación

\title{
The challenge of competencies in training for educational research: a conceptual approach
}

El desafío de la formación en competencias para la investigación educativa: aproximación conceptual

\section{Volumen 19, Número 3 \\ Setiembre-Diciembre}

pp. 1-27

Cristian Velandia Mesa

Francisca José Serrano Pastor

María José Martínez Segura

\section{Citar este documento según modelo APA}

Velandia Mesa, Cristian., Serrano Pastor, Francisca José., y Martínez Segura, María José.

(2019). The challenge of competencies in training for educational research: a conceptual approach. Revista Actualidades Investigativas en Educación, 19(3), 1-27. Doi. 10.15517/aie.v19i3.38738 


\title{
The challenge of competencies in training for educational research: a conceptual approach \\ El desafío de la formación en competencias para la investigación educativa: aproximación conceptual
}

\author{
Cristian Velandia Mesa ${ }^{1}$ \\ Francisca José Serrano Pastor ${ }^{2}$ \\ María José Martínez Segura ${ }^{3}$
}

\begin{abstract}
This article shows the results of the study, which purpose was to reconfigure and develop a conceptual approach to research competences for the strengthening of educational research training processes. The research was conducted in four academic semesters and was based on a mixed approach with a Sequential Transformative Research Design (DITRAS). The process included a stage of documental analysis and systematization of qualitative data that were collected through semi-structured interviews. The second stage included the implementation of the CMI technique, which purpose was to identify categorical systems to classify research competences through the analysis of hierarchical conglomerates. Eleven experts in the area of teaching-research in Higher Education participated, 24 students and 4 alumni from an undergraduate program in Early Childhood Education. The result of the study was to build a conceptual and taxonomic approach to the competencies for teacher-researcher training, which includes 79 learning outcomes that are classified in 29 constructs, and related in 8 competences. The strong theoretical influence in the processes of research training, the gradual devaluation of the experience as an agent in the construction of knowledge, and the pedagogical practice focused on the instrumentalization represent new challenges that go beyond the methodological. These challenges focus on the development of research training processes based on ethics, technology, teamwork and innovation. The final reflections constitute an approach to rethink the academic curricula based on formative research as an agent of transformation and assurance of educational quality.
\end{abstract}

Key words: teacher training, pedagogical research, teacher competencies, higher education

Resumen: El artículo presenta los resultados de estudio cuyo propósito fue reconfigurar y desarrollar una aproximación conceptual entorno a las competencias investigativas para el fortalecimiento de los procesos de formación en investigación educativa. La investigación se efectuó durante cuatro semestres académicos y se fundamentó en un enfoque mixto con un Diseño de Investigación Transformativo Secuencial (DITRAS). El proceso incluyó una primera etapa de análisis documental y sistematización de datos cualitativos recopilados a través de entrevistas semiestructuradas. La segunda etapa incluyó la implementación de la técnica CMI, cuyo objetivo fue identificar sistemas categoriales para clasificar competencias investigativas a través del análisis de conglomerados jerárquicos. Participaron 11 personas expertas en el área de docencia-investigación en Educación Superior, 24 estudiantes y 4 egresadas de un programa de licenciatura en educación inicial. Como resultado del estudio se construyó una aproximación conceptual y taxonómica de las competencias para la formación de maestros-investigadores, que incluye 79 resultados de aprendizaje clasificados en 29 constructos y relacionados en 8 competencias. La fuerte influencia teórica en los procesos de formación investigativa, la desvalorización paulatina de la experiencia como agente en la construcción de conocimiento, y la práctica pedagógica enfocada a la instrumentalización, representan nuevos desafíos que sobrepasan lo metodológico. Dichos desafíos se focalizan en el desarrollo de procesos de investigación formativa fundamentados en la ética, la tecnología, el trabajo en equipo y la innovación. Las reflexiones finales, constituyen un acercamiento para repensar los currículos académicos basados en la investigación formativa como agente de transformación y aseguramiento de la calidad educativa.

Keywords: formación de docentes, investigación pedagógica, competencias docentes, educación superior.

1 Universidad El Bosque, Research Coordinator of the Faculty of Education, Bogotá, Colombia. Electronic address: velandiacristian@unbosque.edu.co ORCID http://orcid.org/0000-0002-7195-3365

2 University of Murcia. Professor at the University in the Area of Research Methods and Diagnosis in Education, Spain. Electronic address: fjserran@um.es ORCID https://orcid.org/0000-0002-5193-209X

${ }^{3}$ University of Murcia. Professor at the University in the Area of Research Methods and Diagnosis in Education, Spain. Electronic address: mjmarti@um.es ORCID http://orcid.org/0000-0001-7022-5780

Artículo recibido: 19 de marzo, 2019

Enviado a corrección: 27 de junio, 2019

Aprobado: 19 de agosto, 2019 


\section{Introduction}

Research, science and technology arise as indispensable channels to build progress policies, advancement and innovation. In this regard, education acts as an influential scenario for social wellness, life quality and for human capital improvement. The university, through research and development, is a fundamental mechanism to extract value from knowledge, make rational statements based on evidence and carry out genuine exercises for quality training (Clavijo-Gallego, 2014). In other words, educational research is a fundamental factor for ensuring the quality of education and belongs to the so-called social and human sciences filed. Educational research is a discipline that aims at understanding phenomena, solving problems and organizing processes based on educational needs and opportunities (Botella and Zamora, 2017).

Training for educational research (TER) is the search and generation of experiences that are transformed into knowledge; it aims at developing students' scientific competencies through actions that allow them responding to educational, social and cultural needs and problems (Baños, Hurtado and Berlanga, 2014). At a comprehensive level, the essential goal of TER is to cultivate knowledge and know-how (García, Angarita and Velandia, 2013). Although TER does not intend to provide final or immediate answers to emerging issues in the educational context, it claims for a reasoned reflection that allows for constructive and academic discussion. It is in this scenario, where TER makes sense, as it is conceived as the process developed for students to be trained for research by starting out from a problematic situation within their curricular and potential professional environment (Chacón, 2014).

In the higher education scenario there are agreements regarding training of researchers as a substantial quality of university identity. It is in the higher education context where students are asked to address topics and develop activities to open and seek spaces to contribute to the development of their own research competencies. It is in this same context that TER is considered a factor that is constitutive in nature and is inherent to academic processes (Durán-Bellonch and lon, 2014). Research plays a fundamental role in students' learning and professional training, and TER seeks to develop and build up permanent skills through actions such as experimentation, reflection, contrasting models, analysis and systematization of academic practices, which intend for students to perform successfully productive activities associated with pedagogical and professional work (Tejada Fernández and Ruiz Bueno, 2016). 
TER is a complex process, due to its diverse and dynamic research nature. In the university context, the proposed learning environments seek to develop knowledge such as the knowing to be, knowing to do, knowing to know and knowing to co-exist, while this process fluctuates between the ideal and the possible (Avendaño-Castro, Rueda-Vera and Paz-Montes, 2016). TER seeks for actions towards the development of creativity and scientific competences in students, and towards conducting research in a strict sense that looks for the enhancement of theory and practice, knowledge production and service research development (Ayala, 2016).

According to the above, quality assurance in higher education, international competitiveness, inter-institutional and curricular cooperation, interculturality, academic mobility, research training, and the use of technologies applied to education and ethics are at the core of the educational process. In addition, these aspects are crucial in governmental agendas of different American countries and the European community (Declaration of Bologna in 1999, Declaration of Prague in 2001, Declaration of Berlin in 2003, Project Tuning-Europe Latin America, Buenos Aires in 2005, Belo Horizonte 2005, San José de Costa Rica 2006, Brussels in June 2006, Mexico in 2007 and ANECA in 2007). The relevance of the mentioned characteristics is given due to the fact that in the higher education horizon there are transformations and schools of thought that explain the educational phenomenon as the fundamental axis of the political, economic, collective, labor and cultural development of society (Velandia-Mesa, Serrano-Pastor and Martínez-Segura, 2017).

The university perspective towards students is to teach to learn, while from the students' perspective it is about learning to learn; both of the perspectives mean skills demanded by the social and labor dynamics. In this way, higher education institutions seek to identify the knowledge, practices and learning outcomes that allow the development of skills and competences (Mayorga-Fernández, Madrid-Vivar and Padial-Díaz, S, 2016).

The limits and scope of TER are linked to a curricular framework defined by the development of research competences and, its relevance is determined by a purely pedagogical nature (Longi, 2018). In other words, TER seeks to consolidate students' research competencies that are transversal to the academic curriculum. According to the Tuning project for Europe and Latin America, by the end of the undergraduate programs, educational science students must be in the capacity to "research in education and apply the results in the systematic transformation of educational practices" (Bravo, 2007, p.24). 
Overall, professional profiles are directly associated with competences based on research, innovation and problem solving, and likewise, the learning outcomes proposed in TER are an essential part of professionalization. Similarly and prospectively, TER intends that students at the end of their undergraduate programs have the ability to "design and implement a research project or teaching innovation in different areas such as Teacher Training quality and educational evaluation" (National Agency for the Evaluation of Quality and Accreditation [ANECA], 2013, p. 55).

\subsection{Problem Statement}

Because of aforementioned considerations, there are several important challenges to be considered for strengthening TER processes; one of them is associated with the evaluation and assessment of research training. Although, the final graduation work and its dissertation approximate the performance of the students in the research training process, these are not the only referents. Nevertheless, we cannot ignore the progress made and the good intentions of TER in this regard, it is important not to focus the objectives of research training on a document or monograph only (Delgado Camacho, Guzmán and Mora Ramírez, 2009). Instead, it is necessary to understand TER as comprehensive knowledge, not only based on method and semiotics, inviting us to approach research training from the knowledge dimension and know-how perspectives.

On the other hand, the proliferation of higher education institutions that recognize research as a substantial quality of university identity and as a key factor to the social development of a country contrasts with the substantial needs in terms of evaluation, research service and research training that must be looked after within the framework of TER. However, Biesta (2007), Kennedy (1997), Lavis, Robertson, Woodside, McLeod and Abelson (2003), Mortimore (2000), and Murillo and Perines (2017) question the limited contribution of educational research in the optimization of processes, the formulation of actions, decision making and the application of alternative solutions to problems. Taking into account the literature reviewed and contextual analysis, the research problem focuses on the fact that training in educational research is usually conducted taking into account traditional (in a linear behavior) competencies models, which focused exclusively on knowledge developed by students. On the contrary, in reality (in an exponential nature), models of development of research competencies that can be adapted to the permanent transformations are required; such models must be based on innovation, entrepreneurship, 
teamwork, ethics and technology. Consequently, an increasingly wide gap has been identified between the competencies proposed in formative research and the demands of educational research in an academic context that is permanently rebuilt.

\subsection{Objective}

The described issues bring great challenges regarding the redefinition of learning outcomes, products, competencies, limits and scope of formative research and its link with educational practice. The diverse and dynamic nature of the training processes in research leads to conceptual analysis, an update of evaluation processes, identification of new learning objectives, and the implementation of new actions in research that could contribute to education. These issues lead to the development of a conceptual analysis regarding research competences, which lead to the strengthening of evaluation and training processes for educational research. From this perspective, a reflection has been built as to the competences in educational research that will lead to rethinking the academic curriculum vs. the assessment and the role of training processes in educational research. The competences for TER imply their comprehensive understanding as related elements that are in permanent interaction. However, they have been fragmented into different constructs in order to give greater clarity to the analysis. From this perspective, this study aimed at suggesting a model of research competencies that can be adapted and that can anticipate what different educational scenarios required, a model based on ethics, technology, teamwork and innovation.

Through this study, we seek to participate in the strengthening and consolidation of an academic curriculum based on research-reflection, in virtue of the considerations generated from the analysis of competences in educational research. The following four sections correspond to: First, the conceptualization of research competencies oriented to the scenario of educational sciences; second, the specific methodology applied during the study and, subsequently, the third section presents the discussion about the systematization and analysis of the results regarding the competences and learning outcomes in TER. The article closes with some final reflections on the TER process in the field of education, by exploring the limitations and implications of the study. 


\section{Theoretical framework}

This short review of literature aims at unveiling how educational research is linked to educational models in a historical process. Although, this study took place in the Colombian context, understanding its development and how educational research has evolved is relevant to know how in the Colombian context is has been adopted.

TER is associated with university history, in which the German and Anglo-Saxon educational models base their training on the freedom of teaching and instruction, the inclusion of research and the economic intervention of the state in universities (Barnett, 2008). At the beginning of the 19th century, the University of Berlin, based on Humboldt's postulates, gives a fundamental role to research (Research University) based on the university-business link while highlighting technology transfer and applied research to the market (Chaves Salas, Kunze, Müller-Using and Nakamura, 2017).

The most important pillar in the German model is the relationship between teaching and research; Barnett (2008) points out that in universities, teaching should be considered in a research mode. Likewise, the Anglo-Saxon model considers universities such as Cambridge and Oxford, which develop a method based on the training for solving research problems. The research task becomes stronger from these classic university models, establishing scientific and research training as an essential part of professional training. In different countries of the Latin American region, we have opted for models based on teaching and research, where the generation of knowledge is the fundamental basis of university philosophy (Campos Céspedes and Chinchilla Jiménez, 2009).

Entering the TER scenario would lead us to consider its development and evolution as seen from its nature, paradigms, epistemological and methodological aspects. Considering this situation, we will approach TER from the relationship between research and the teaching-learning processes. Around the $60 \mathrm{~s}$ of the last century, state and government entities drew educational policies considering fundamental professionalization, updating, and permanent teacher training as part of the improvement of the educational system (Dewey, 1937). In this process, all the academic forces are included to reflect upon pedagogical practices and teachers' work. This leads to the inclusion of the "teacher-researcher" concept in the early 70's in Britain, linked to a current based on processual curricular development, which focused academic efforts on the teaching-learning processes based on research hypotheses (Stenhouse, 1998). In the decade of the 80's, Elliott and Adelman (1984) placed 
the teacher as a fundamental actor in the research processes and incorporated triangulation as a methodology in educational studies.

This academic movement suggests educating teachers who solve problems, theorize and investigate in the classroom, a process that should be carried out from the teachers' reflection on their own behavior to progressively reconstruct the curriculum. In Spain, an approximation of the ideal teacher profile is built, and some reforms related to the competences of an active researcher are affected (Porlán, 1988).

In Latin America, a profile for a researcher-teacher is suggested in the different models of teacher training. The first is through the construction of work hypotheses based on the conceptual errors of actors or students; the second, the inclusion of evaluation as a substantial part in the research model in the classroom; and the third, the development of a research culture in the academic setting and the incorporation of scientific competences as part of training (Gimeno, 1984). In this way, a generation of professors who are part of an educational system that validates the need to incorporate research as part of comprehensive education to support social and community policies begins to be built worldwide.

\subsection{Competencies in Training for Educational Research}

This study takes a working definition on research competence based on the reflection of the etymological, systemic, and epistemological approaches to the concept. In the first place, the term research competence could become a polysemous expression (Díaz-Barriga, 2011). From an etymological perspective, the word competence is associated its Latin origin competere, which means: a person responsible for being. Likewise, the term research comes from the Latin investigare (in Spanish investigar), derived from the word vestigio which means to embark on the search of traces. In this way, this study relies on the meaning of research competence as the responsibility of following the tracks.

From a systemic approach, research competences justify that "everything that is learned in research, does not necessarily have an immediate usefulness for life" (DíazBarriga, 2011, p. 10), and the expression research competence can be defined as the knowledge, skills and abilities to live and coexist. Regarding the pedagogical current, also called socio-formative or complex approach within research competencies, experience is highlighted as an essential foundation for learning, pointing out that training plays a relevant role in the cognitive, pragmatic and attitudinal aspects. 
Although there are many convergences and divergences that make it difficult to define research competence, because its structure is based on approaches, research lines, epistemological paradigms, contexts and research scenarios, the contributions of Tirado et al. (2006), Bautista (2009) and Herrera-González (2012) enable us to adopt a position to define and work with the definition of research competence as:

(...) an identifiable and evaluable set of knowledge, skills, values and attitudes related to each other, which allow satisfactory performance of research projects in real situations according to the standards used in a given area. Thus, competences refer to successful research performance and therefore integrate being, knowledge and doing in a given context (Tirado et al., 2006, p. 2)

TER, through the development of research skills becomes a significant challenge, associated to degree profiles, academic curriculum, and pedagogical practices and training routes (Alfaro and Alvarado, 2018). Because of professional requirements, social dynamics and attention to the fundamental intention of TER, a great interest has been awakened as to the resolution of the acquisition of ability problems (doing), learning to learn (knowing-how) and ethical research discernment (knowing how to be):

(...) in the training for research competences, three fundamental aspects are integrated: the cognitive aspect, which leads to the appropriation, understanding and internalization of knowledge; the implementation of skills or abilities that brings about the application of knowledge; and being, as the most important aspect of the training process considering its attitudinal and behavioral nature (Pérez Rocha, 2012, p.10)

\section{Methodology}

Taking into consideration that this study aims at identifying learning outcomes and classifying them in terms of research competences, this study follows a sequential transformative research design DITRAS (Hernández Sampieri, Fernández Collado and Baptista Lucio, 2010). The DITRAS design allows the analysis of qualitative data based on the classifications that are found in the analysis of the quantitative data. The nature of the study goes along with the DITRAS design in the sense that both entail meaning-making processes from qualitative as well as quantitative data (Creswell, 2013).

The design included two stages of information gathering. A first moment focused on document collection and systematization of qualitative information through semi-structured 
interviews with teachers-researchers who develop their educational process from educational research, as well as with students and graduates of the undergraduate program, whose goal was to recognize the objectives, learning outcomes and competences in TER.

The identified learning outcomes, that were the product of the qualitative data collection moment, were then classified in groups that became the input to run data in the quantitative stage. The groups of information that resulted from the qualitative stage were then analyzed through the technique of multidimensional scalogram analysis, this with the purpose to organize, classify and associate the identified learning outcomes to educational research competences as a fundamental part of the in training researcher- teacher profile which included conglomerates, competency assessment scales and evaluation of judges. Finally, data was analyzed following the DITRAS design that suggests triangulate data from theoretical and contextual perspectives.

\subsection{Study Population}

Participants in the study were divided in two groups and selected according to their profile as teacher-researchers, thesis tutors, and teacher-researcher trainees. The first group was a panel of 11 experts that were selected considering their experience in research training, academic work, and actions related to educational practice ( 2 from Universidad de Murcia, Spain; 7 from Universidad El Bosque in Colombia; 1 from Universidad de Los Andes in Colombia; 1 from the State University of New York at Buffalo, USA). The selected experts contributed through the systematization of their research experience. The second group was one of 24 students from the undergraduate Honors Degree in Early Childhood Education program from Universidad El Bosque in Bogotá, Colombia, (ages 23-28) and 4 alumni from the Education program who developed research and systematization processes in their work contexts.

\subsection{Collection techniques}

Based on the proposed methodology and after the analysis of the documents, the application of semi-structured interviews was carried out in a first phase, which was characterized by the configuration of four stages (informed consent, situational factors, training strategies and process of evaluation), in order to build an approach to the limits, scope and learning outcomes of TER. Subsequently, a questionnaire based on the multiple classification technique was used; this data collection technique (Pacheco, 2010) provides participants with the possibility to classify learning outcomes through digital cards, of knowing 
the interrelation of criteria through the organization of information and the use of multidimensional scalograms, which aimed at identifying categorical systems that support the reconfiguration of the research competence models (Pacheco, 2010, Páramo, 2018). The multiple classification technique "is a multi-dimensional scale that aims at evaluating variables with quantifiable and non-quantifiable characteristics" (Pacheco, 2010, p.26).

The validation process of the instruments used in both stages consisted of two phases called content validity and construct validity. Content validity covers five moments: The first focused on the development of a theoretical sampling to determine the convergences and divergences regarding the learning outcomes, competences and objectives of TER. A second moment was determined by the information collected through a semi-structured interview, in which its elements supported the articulation between theory and contextual needs.

In a third stage, we proceeded to the construction of a matrix of components (dimensions and learning outcomes) contrasting the models of ANECA (2013) in Spain and the Colombian CNA model (2013), as guarantor organizations in the evaluation of the quality of higher education, which is the context in which the study is developed. The decision of considering these two models (CNA and ANECA) was made due to their relevance and influence they hold in the context of this study. The fourth moment included the expertise of Spanish and Colombian expert and focused on the evaluation of content by using concordance index (structure, writing, depth, cohesion). The validity construct was developed based on multivariate statistical technique of hierarchical clusters based on the Ward grouping method, which allowed to match, classify and organize learning results through competences for TER, in its three dimensions (Knowing, Knowing How and Knowing how to be).

\subsection{Analysis processing}

The systematization and analysis of qualitative data was developed through: 1) The distillation of information, which implied the selection of units of analysis for the centralization of data and identification of patterns 2) The open and selective coding, which required an initial taxonomic construction of the competencies for TER. The qualitative data were structured taking into account deductive categorization criteria from the documentary and contextual analysis, as well as the clustering models through hierarchical cluster analysis based on the Ward grouping method. 3) Diagramming of semantic networks corresponding to each criterion, which characterizes the competences of TER. This process included the 
determination of density (relationships) and weight (voices) for each of the categories of analysis. 4) Finally, a triangulation process was carried out (theoretical-contextualargumentative) by contrasting theoretical information (documentation and quality models), contextual data (data of the context of occurrence) and the positions of the researchers, which supports the investigative rigor during the data analysis. This process was assisted through the Atlas IT version 8 software.

The quantitative information collected during the application of the multiple classification technique, which is a "multidimensional scale, by means of which it is intended to identify categorial systems" (León Acosta, Vallejo Ovalle, Parra Carrasquilla and Obregoso Rodríguez, 2010, p. 6) and allowed the construction of a matrix (11 Experts vs. 79 Learning Outcomes) with 29 classifications corresponding to each TER component. The resulted values were incorporated into the SPSS Software 24 to obtain the proximities matrix as part of the classification process, through the hierarchical conglomeration method, based on the Ward model and Euclidean distance.

\section{Results and discussion}

The analysis of clusters through hierarchical cluster classification allowed the classification of 79 learning outcomes per TER in eight groups (competences), which were based on three dimensions (knowing, doing and being) achieving maximum homogeneity and minimum variance. The following proximity matrix was obtained (Table 1) based on the Ward grouping method with squared Euclidean distance measure:

Table 1.

Matrix of proximities. Cases of learning outcomes in Research Training

\begin{tabular}{|l|c|c|c|c|c|c|c|c|c|c|}
\hline Caso & 1 & 2 & 3 & 4 & 5 & 6 & 7 & 8 & 9 & 8 clúster \\
\hline 1 &, 000 & 41,0 & 20,0 & 42,0 & 209 & 184 & 466 & 11,0 & 15,0 & 1 \\
\hline 2 & 41,0 &, 000 & 71,0 & 25,0 & 110 & 93,0 & 299 & 36,0 & 60,0 & 1 \\
\hline 3 & 20,0 & 71,0 &, 000 & 80,0 & 297 & 254 & 600 & 15,0 & 17,0 & 1 \\
\hline 4 & 42,0 & 25,0 & 80,0 &, 000 & 99,0 & 92,0 & 292 & 35,0 & 57,0 & 1 \\
\hline 5 & 209 & 110 & 297 & 99,0 &, 000 & 39,0 & 81,0 & 208 & 256 & 2 \\
\hline 6 & 184 & 93,0 & 254 & 92,0 & 39,0 &, 000 & 96,0 & 185 & 219 & 2 \\
\hline 7 & 466 & 299 & 600 & 292 & 81,0 & 96,0 &, 000 & 469 & 531 & 2 \\
\hline 8 & 11,0 & 36,0 & 15,0 & 35,0 & 208 & 185 & 469 &, 000 & 12,0 & 1 \\
\hline 9 & 15,0 & 60,0 & 17,0 & 57,0 & 256 & 219 & 531 & 12,0 &, 000 & 1 \\
\hline 10 & 135 & 172 & 179 & 115 & 246 & 263 & 465 & 138 & 188 & 3 \\
\hline
\end{tabular}

Note: each case corresponds to the learning objectives proposed in the research training process. However, due to the limited space, only the distances of the 10 initial results are showing. Source: Researcher's own design (2018). 
The matrix, that is now graphically represented in the dendrogram (see Figure 1 part $A$ ), allowed to identify the proximity between the learning outcomes and 8 groups, whose classifications confirmed and explained the competences in formative research. Subsequently, a dispersion chart was built (see Figure 1 part B); this chart allowed identifying and explaining the classification of learning outcomes in initial categories. The scatter plot only includes the 30 most significant weight and density learning outcomes, based on the analysis of voices and theoretical sampling (qualitative analysis).

Figure 1. Dendrogram and classifications in dispersion graph based on proximity matrix.

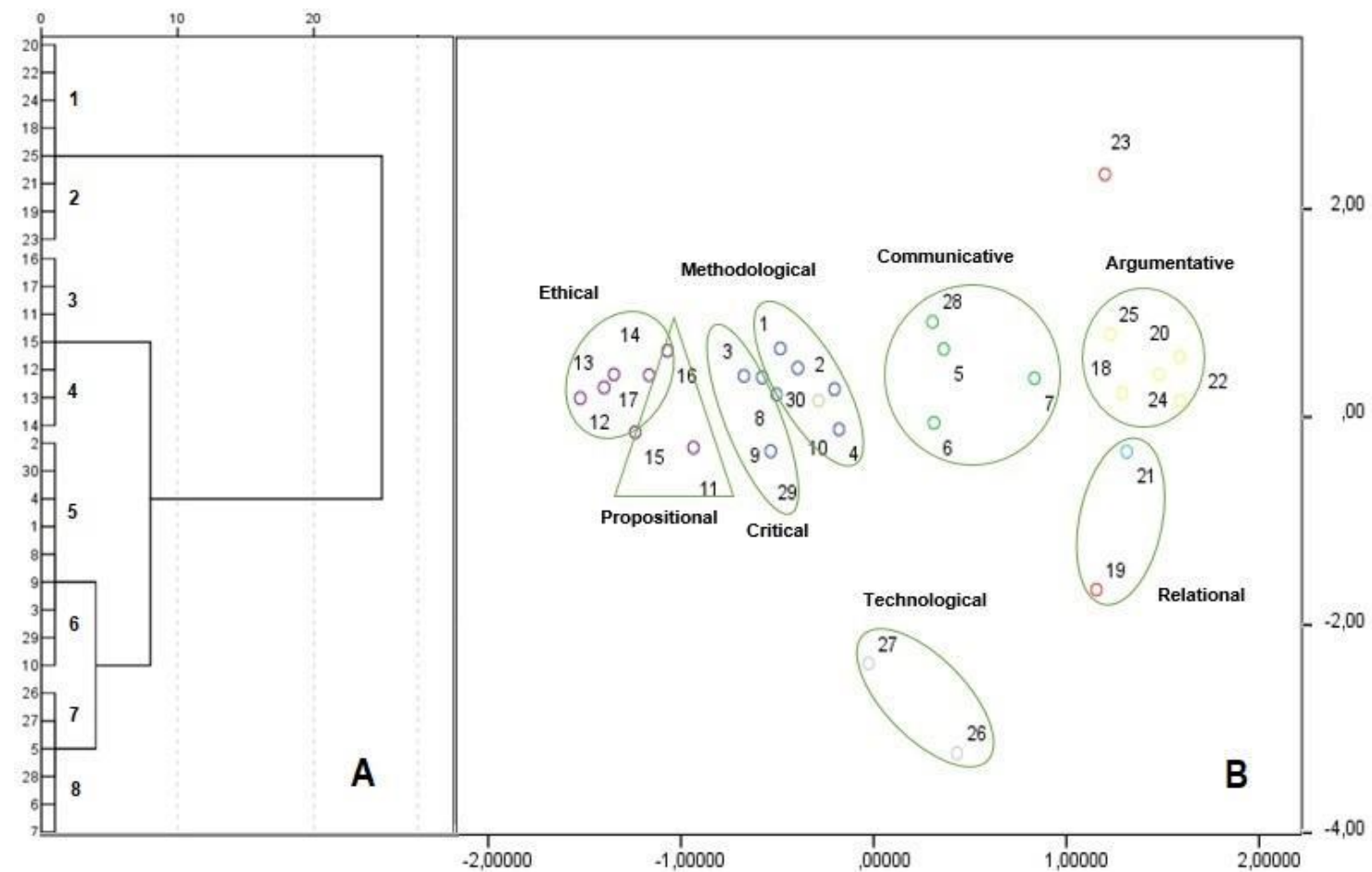

Source: Researcher's own design (2018)

Based on the identification and classification of the learning results (quantitative data) and the data analysis results through the triangulation process (qualitative data), a conceptual taxonomic approach of competencies in educational research training is presented. The triangulation based on the voices of the context compared with the theory and the position of the researcher, allowed to identify competencies and constructs as part of the fundamental criteria for evaluation of TER. Based on the values of density (number of associations) and weight (number of quotes identified in the collected data) associated to each category (Table 2), 9 competences were identified for training in educational research related to: 
communication, analysis, argumentation, research ethics, use of technologies, relational capacity, critical thinking, the method and the proposition.

Table 2.

Density and weight for TER constructs,

\begin{tabular}{|c|c|c|c|c|c|c|c|c|c|}
\hline \multirow{2}{*}{ Competence } & \multirow{2}{*}{ Constructs } & \multicolumn{4}{|c|}{ Weight } & \multicolumn{4}{|c|}{ Density } \\
\hline & & 1 & \begin{tabular}{|l|l|}
2 & 3 \\
\end{tabular} & 4 & 5 & 1 & 2 & & \begin{tabular}{l|l}
4 & 5 \\
4
\end{tabular} \\
\hline \multirow{3}{*}{ Communicative } & Academic Writing (R28) & & & & & & & & \\
\hline & Oratory (R5) & & & & & & & & \\
\hline & Dissemination (R7) & & & & & & & & \\
\hline \multirow{2}{*}{ Technological } & $\begin{array}{l}\text { Application resources to information } \\
\text { management (R6) }\end{array}$ & & & & & & & & \\
\hline & $\begin{array}{l}\text { Software domain for data analysis (R27) } \\
\text { Record resources and data collection (R26) }\end{array}$ & & & & & & & & \\
\hline \multirow{4}{*}{ Argumentative } & Claim (R18) & & & & & & & & \\
\hline & Backing (R20) & & & & & & & & \\
\hline & Warrant (R25) & & & & & & & & \\
\hline & Rebuttal (R20) & & & & & & & & \\
\hline \multirow{4}{*}{ Ethical } & Information Management (R13) & & & & & & & & \\
\hline & Manipulation of Information (R12) & & & & & & & & \\
\hline & Elements of the Ethics code (R17) & & & & & & & & \\
\hline & Consent and assent (R14) & & & & & & & & \\
\hline \multirow{4}{*}{ Methodological } & Research Methodology (R1) & & & & & & & & \\
\hline & Systematization (R2) & & & & & & & & \\
\hline & Procedural capacity (R30) & & & & & & & & \\
\hline & Cognitive abilities (R4) & & & & & & & & \\
\hline \multirow{4}{*}{ Relational } & Teamwork & & & & & & & & \\
\hline & Intra and interpersonal relationships (R23) & & & & & & & & \\
\hline & Adaptation (R19) & & & & & & & & \\
\hline & Communication (R21) & & & & & & & & \\
\hline \multirow{3}{*}{ Critical } & Art of questioning, Interpretation (R3) & & & & & & & & \\
\hline & Analysis, Evaluation, Inference (R8) & & & & & & & & \\
\hline & Self-regulation, Justification. (R29) & & & & & & & & \\
\hline \multirow{4}{*}{ Propositional } & Decision making (Flexibility Fluency) & & & & & & & & \\
\hline & Formulation of actions (R16) & & & & & & & & \\
\hline & Solution alternatives (R11) & & & & & & & & \\
\hline & Motivation (intrinsic/extrinsic) (R15) & & & & & & & & \\
\hline
\end{tabular}

Note: Record generated during the systematization and processing of the qualitative data in Atlas IT version 8 software.

Source: Researcher's own design (2018) 
After the initial analyses, the discussion of the results was developed in the light of the research statement, the theoretical references, and the analysis of the contextual data obtained. This discussion to characterize and develop a conceptual approach to educational research competencies:

\subsection{Communicative Competence in TER}

It is necessary to highlight, that every professional in the area of education must consolidate his/her communicative competence in research based on three elements: academic writing, oratory and dissemination. Analyzing communicative competence as a capacity that involves the integration of attitudes, values and knowledge associated with the use and characteristics of language is a complex exercise, since its development is associated with experience, motivations and needs that are typical of a culture or a social environment. Hence, the communicative competence in TER processes is conceived as a space for academic and cultural representation which permanently builds its meaning through participation and linguistic socialization. Communicative competence is not limited to semiotic and grammatical systems or to language management but involves interacting in a specific scenario and applying primary (daily) and secondary (elaborated and complex) communication systems.

Communicative Competence in TER includes linguistic capacity which is the the ability to interpret, create, produce and approach meaning, through a system of signs, which corresponds, in other words, to the semiotic domain. Likewise, the semantic use is part of communicative competence. Its function corresponds to the ability to communicate.

Regarding TER focused as a strategy for the development of communicative skills, the paralinguistic competence understood as the ability to express linguistic and non-linguistic signs appropriately is highlighted. From orality, it manifests itself in pronunciation, tone of voice, among others, while in academic writing it comes across as part of the grammatical rules and elements of form. Communication as a fundamental factor for TER involves efforts in the development of kinesthetic (gestural signs), proxemics (relational codes), pragmatic (research communicative acts) and stylistic (communicative efficacy) abilities.

\subsection{Technological Competences in the TER}

Today, technological resources play a leading role in research processes and in TER, since they allow the collaboration, cooperation, structuring, classification, analysis and 
dissemination of information. However, there are still many issues to analyze and reflect upon as to the use of technologies in research processes, associated, among others, with digital ethics, the dimensions of application, the use of information and the technological competences applied to research.

In the first place, it is important to differentiate between the concept of technological competences and digital competences in research, computer skills and technical competences. It is fundamental to highlight that the technological competences applied in research processes are defined as the link between knowledge, skills and behaviors, required when using technological resources in the foundation, systematization, analysis, problem solving and dissemination of new knowledge (Velandia-Mesa et al., 2017).

In Colombia, the Ministry of ICT and MEN have built a conceptual approach regarding technological competences in research processes and their training. The approach was possible by considering the proposals by UNESCO, the International Society of Education Technology (ISTE), the 21st Century Skills Partnership and the American Association of Colleges of Teachers (AACTE) in the USA, the European Commission DIGCOMP in the framework for the development and understanding of digital competence in Europe, ICT Competencies for teaching in the Spanish public university (Prendes, 2010), ICT Competencies and Standards for the teaching profession (Chile), among others.

When laying research foundations, it is necessary to have the ability to search, filter, edit, classify, evaluate and manage information. To this end, technological tools are used, focusing on project planning, scientific databases, reference managers, editing software, analysis of documents and records among others.

The interaction with technologies and the netiquette are a fundamental part of the collection, systematization and data analysis phase. During this stage, the researcher is expected to be able to use tools to diagram, categorize, explore, relate, predict, and infer; by using resources associated with the software for qualitative, quantitative and mixed data collection, processing and analysis.

During the dissemination phase of the research process, researchers are expected to have participation and digital identity skills, collaboration through digital channels, development, integration, and re-elaboration of content and in some cases capacities for programming, coexistence and computer security. While it is important to achieve skills for the use and application of technological resources in research processes, discovering and 
articulating ethical dilemmas are, in essence, key to the use of computer technology in science (Velandia, Pastor y Segura, 2018).

\subsection{Argumentative Competence in TER}

Being considered as a fundamental part of the competences in TER, the argumentative ability is conceived as a "sequential process that allows inferring conclusions from certain premises" (Rodríguez-Bello, 2004, p.3). In TER processes, argumentation is traditionally associated with defense and academic discussion, orally or through writing, where the niche is determined by "winning or losing arguments" (Toulmin, 2003). However, the fundamental pretension must be linked to epistemic acts focused on production and the generation of new knowledge.

According to Aristotelian postulates, reasoning is a substantial part of argumentation, and it is naturally considered as one of the fundamental factors in educational research, as part of human understanding related to ethos, logos and pathos. In the academic framework, which intends to build, produce and disseminate new knowledge, argumentative ability is a substantial and transversal requirement to the entire research process.

The research argument is based on observation, evidence, systematization and analysis, which leads to reflections that aim at transforming social, cultural and educational contexts. Toulmin (2003) proposes a research rhetoric within the framework of epistemological argumentation as an essential part of knowledge construction. However, argumentative validity in educational research is associated with relevance and with strengthening and transformative actions for the context. The argumentative competence in TER, is based on the elements that constitute the Toulmin model (2003): the claim, the data, the warrant, the backing and the rebuttal. Such components are fundamental to develop argumentative ability.

The assertion understood as the premise, the thesis or the subject that is intended to be reasoned through arguments either orally or in writing, is relevant in the processes of argumentative construction. Evidence is associated to the data, the information and the reasons of the construct, that is, it is conceived epistemologically as vulgar and / or popular knowledge elaborated from observation; the beliefs and premises detached from the opinion, could also serve as a basis for argumentation. Although the thesis and the evidence (facts) are relevant as a reasoned construction, they are not enough to rigorously establish argumentative communication in research processes. It is appropriate to include some 
warrants understood as communication channels between assertion and evidence. The warrants (rules) support and justify the evidence as part of an appropriate argument. At the epistemological level, the warrant is based on practical and systemic knowledge.

Likewise, support, as a fundamental component of the argument contributes to the rational validity, research endorsement and academic rigor. The backing articulates the credible arguments with greater authority to the research postures. In this sense, at the epistemological level, support could be associated with scientific and investigative knowledge. The divergence, appeal and convergence of criteria are a fundamental part of the academic research debate. Accordingly, reason is prone to refutation, which leads to the understanding of the research argument, as a benevolent exercise free of impositions, which has a purpose that is not necessarily related to universally accepted considerations (see Figure 2). This argumentative element is called rebuttal, making it possible for objections to arise, formulated in academic processes and accepted within the framework of ethical research.

Figure 2. Semantic Network. Factors associated with argumentative competence in the TER.

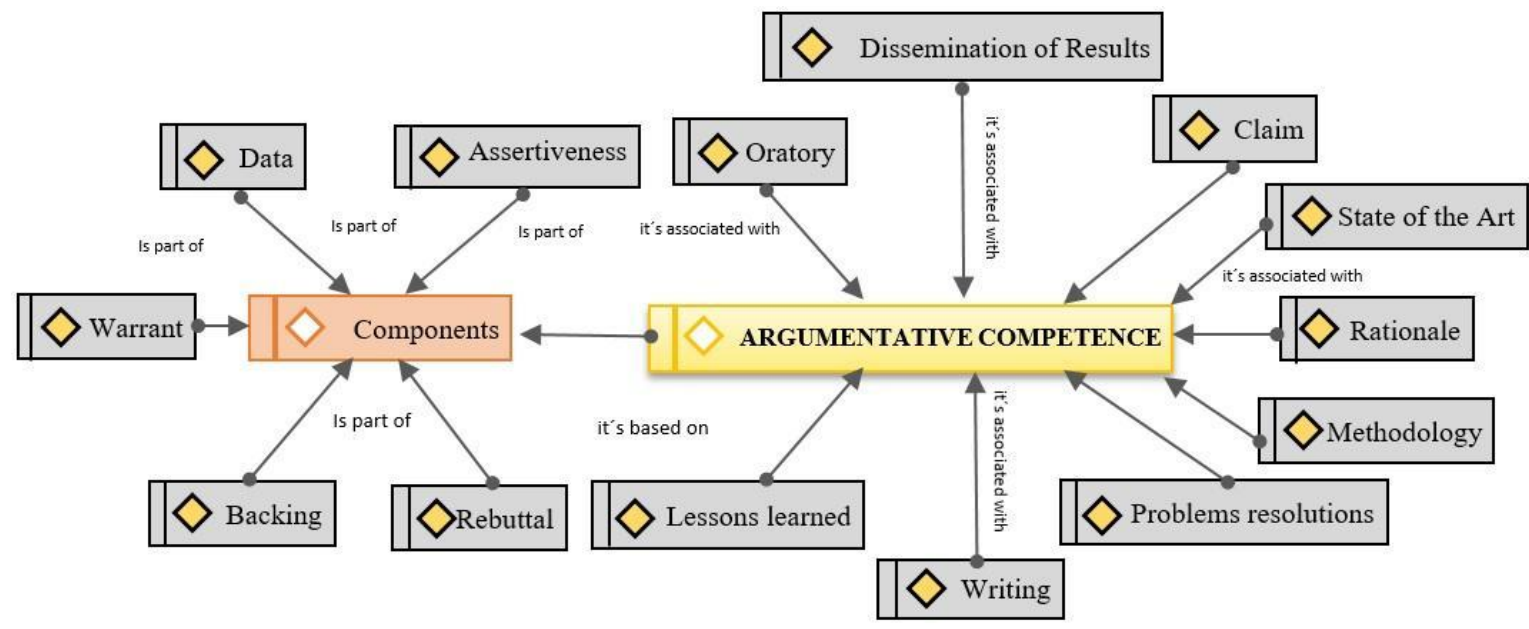

Source: Own elaboration based on the systematization model (Velandia-Mesa et al., 2017)

\subsection{Ethical Competence in TER}

Research ethics, an aspect that is transversal to the fundamental dimensions of competences (knowing, knowing how and knowing how to be) implies a constant reflection of the situations that lead to decision-making, not only determined by a social group, or by the moral philosophy of some creeds, but because research itself must be an ethical act. TER requires the construction of appropriate actions and behaviors, which have a niche framed in 
the conception of research as a responsible and sensible act in relation to intentional effects versus those achieved.

This is how TER processes, avoid harm and avoid unconscious actions before, during and after the development of an investigation. One of the fundamental scopes is associated with learning and the application of some codes of ethical and moral order, which have the objective of determining some rules of action during the development of educational research projects.

Likewise, TER includes the application of ethical codes related to the researcher's behavior, methods, and techniques and especially in the contributions of the study. That is why educating in and for research with an ethical sense, considers an exercise with a greater scope regarding reflection on values and anti-values, first implying, and then generating a culture of behavior with equity and fraternity. The inclusion of ethics and values are considered as emancipatory processes which have the purpose to give substantial value to the actions of researchers, where the role is not only the criticism of reality, but also to understand reality as part of the criticism.

\subsection{Methodological Competence in TER}

The articulation between cognitive and procedural skills, make up the methodological capacity of an educational researcher. The knowledge that is built in practice constitutes the opportunity to strengthen and consolidate TER processes. In this way, we can approach the conception of TER processes as construction developments that interact, where scientific knowledge is the result of action in reality, and is determined by the profile and initial conditions of the context.

In TER processes, students are expected to recognize objects of study in their context of occurrence based on problems, needs or educational opportunities, in the light of the criteria expressed by various authors and academic peers. The application of techniques and instruments for collecting information, favor the construction and systematization of educational experiences in practice scenarios. The analysis of information allows students to develop logic and criticism as part of the acquisition of scientific knowledge, as well as autonomous learning.

From the approach of problems to the formulation of proposals, it is intended to motivate students and teachers to contextualize research objects that integrate cognitive structures, skills development, aptitudes and attitudes. Methodological competence includes: 
experimentation, application of knowledge in specific situations, formulation of questions, and research objectives related to the scenario of occurrence. It also implies planning, constructing theoretical referents based on a disciplinary knowledge related to the study, understanding and using methods, approaches and techniques in educational research, elaborating materials, systematizing information and reflecting based on theory.

\subsection{Relational Competence in the TER}

In the field of educational research, cooperative and collaborative work has been fostered based on the roles played during planning, execution and research production. During TER, situations arise in which social and emotional relationships are considered as opportunities for research consolidation, academic productivity and job satisfaction. Liaising between pairs brings about better productive results than an individual research work (Torrelles et al., 2011). Based on these premises, crosscutting relational competence is considered, due to its prominence in all phases of the research process. Vygotsky states that most of the things that an individual learns and internalizes are associated with relationships and interactions with others in a particular context.

Baker (2006) and Torreles et al., (2011) establish some components of relational competence based on: decision-making, interpersonal relationships, communication (verbal and non-verbal language skills), follow-up, conflict resolution, adjustments, leadership, negotiation and commitment (see Figure 3). Supported in the systematized documentation from primary (context) and secondary (theory) sources. An approximation of the main components of the relational competence in TER are: 
Figure 3. Semantic Network. Factors associated with relational competence in the TER.

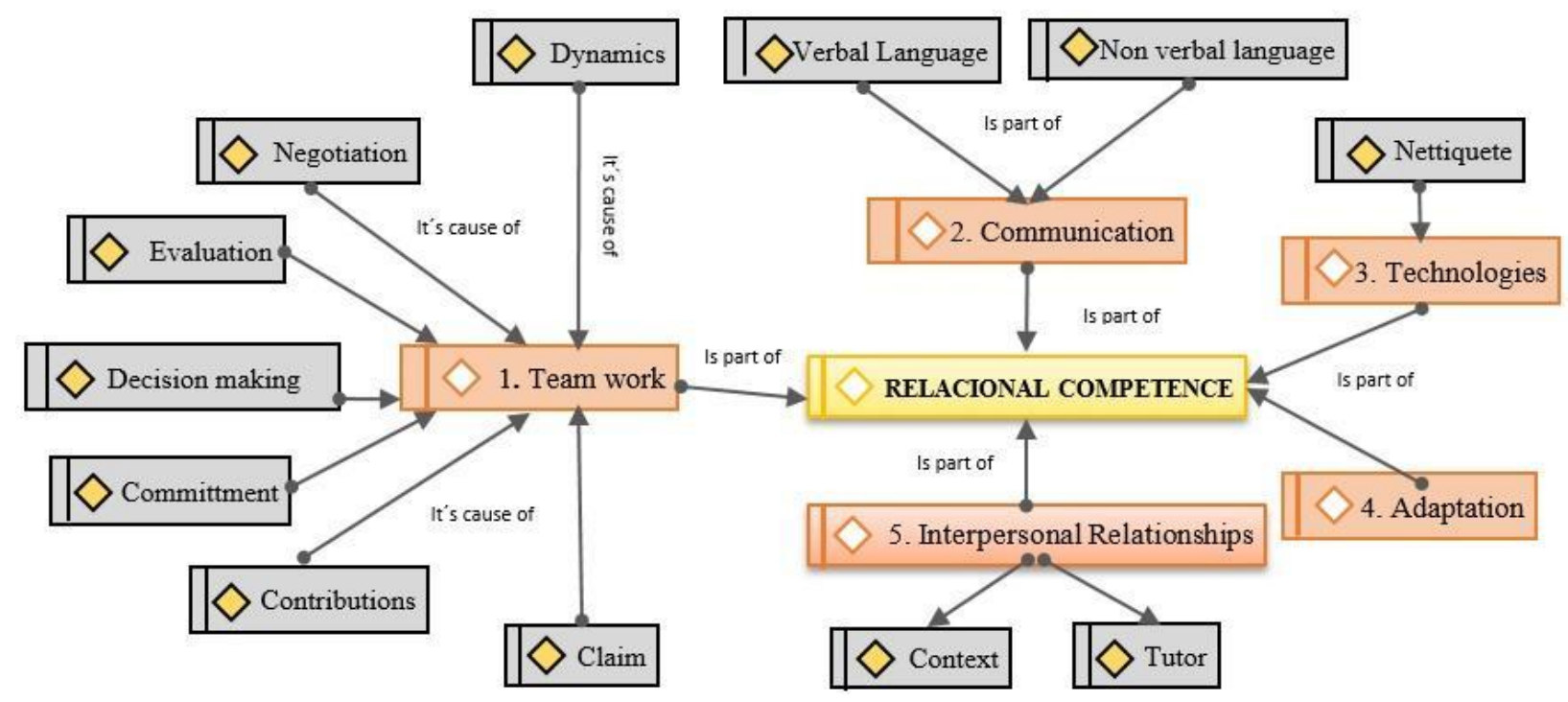

Source: Own elaboration based on the systematization model (Velandia-Mesa et al., 2017)

\subsection{Critical Competence of TER}

Analyzing this competence implies an exercise of great complexity, because the concept is linked to a disciplinary knowledge, a context and a knowledge domain. Focusing on TER, critical competence is highly related to knowing how to ask, and it is understood as a process that links interpretation, analysis, inference, evaluation, explanation and selfregulation, with elements of the environment, in order to achieve transformations of thought that underlie creativity (Paul and Elder, 2005).

Focusing the analysis on the skills, knowledge and attitudes that are sought to be developed in TER, an approach to the concept of critical competence has been constructed, segmenting the term into different components; however, critical thinking, as well as creative thinking, implies understanding them as elements that are in constant dialogue (see Figure 4). Thus, the proposed classification for critical competence in TER, includes the following elements: 
Figure 4. Semantic Network. Factors associated with critical competence in the TER.

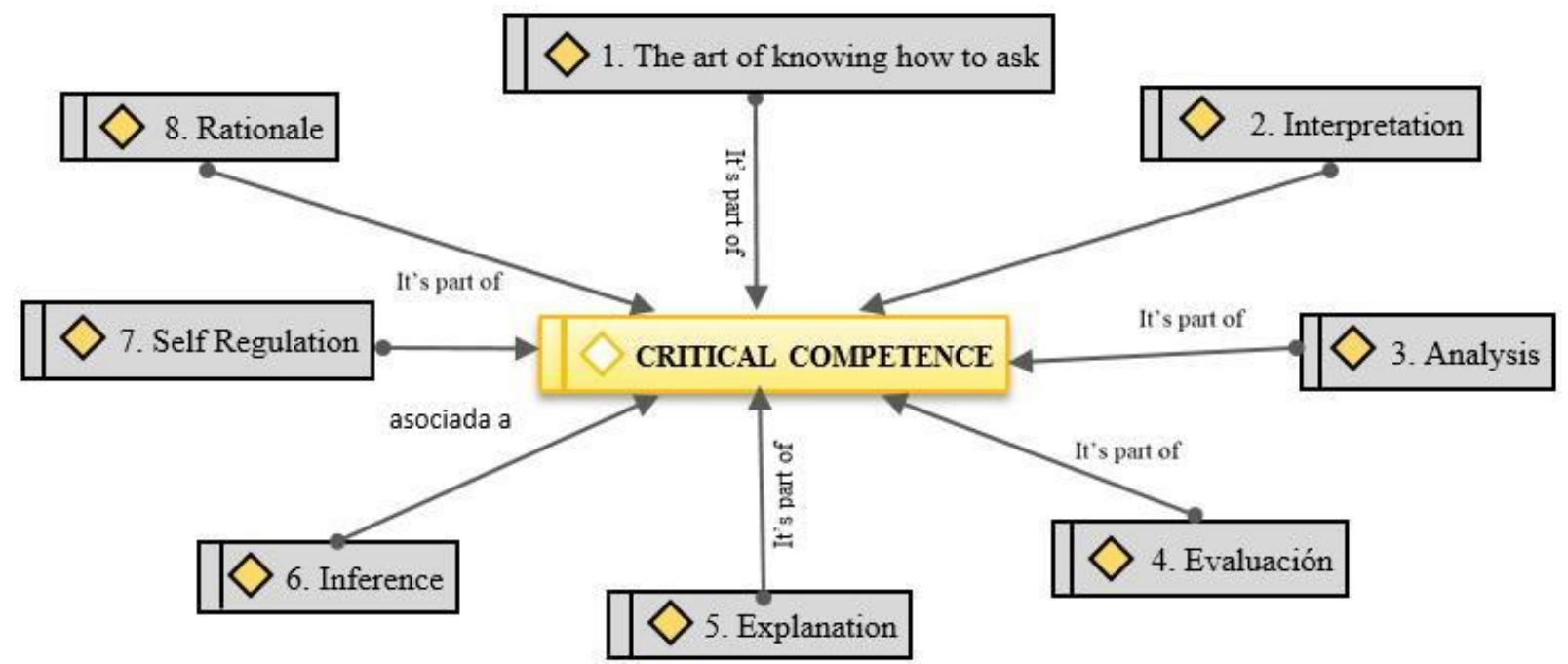

Source: Own elaboration based on the systematization model (Velandia-Mesa et al., 2017)

\subsection{Propositional Competence in TER}

Based on the premise that knowledge and skills add up, but attitudes multiply, the competence of proactivity in TER is a concept linked to entrepreneurial and innovative capacity. Its components are determined by decision-making skills, the formulation of actions, the development of alternative solutions, the generation of hypotheses and motivation.

Likewise, the evaluation of proactive competence is related to flexibility, fluency and originality, from the construction of presumptions to the execution of actions, which lead to problem resolution (see Figure 5). In TER, the elements related to propositional competence play a fundamental role in a transversal way throughout the research process; however, they are accentuated in the approach, the formulation, the construction of materials, systematization and research projections. In this way, the proposed classification for proactive competition in TER includes the following elements: 
Figure 5. Semantic Network. Factors associated with proactive competition in TER.

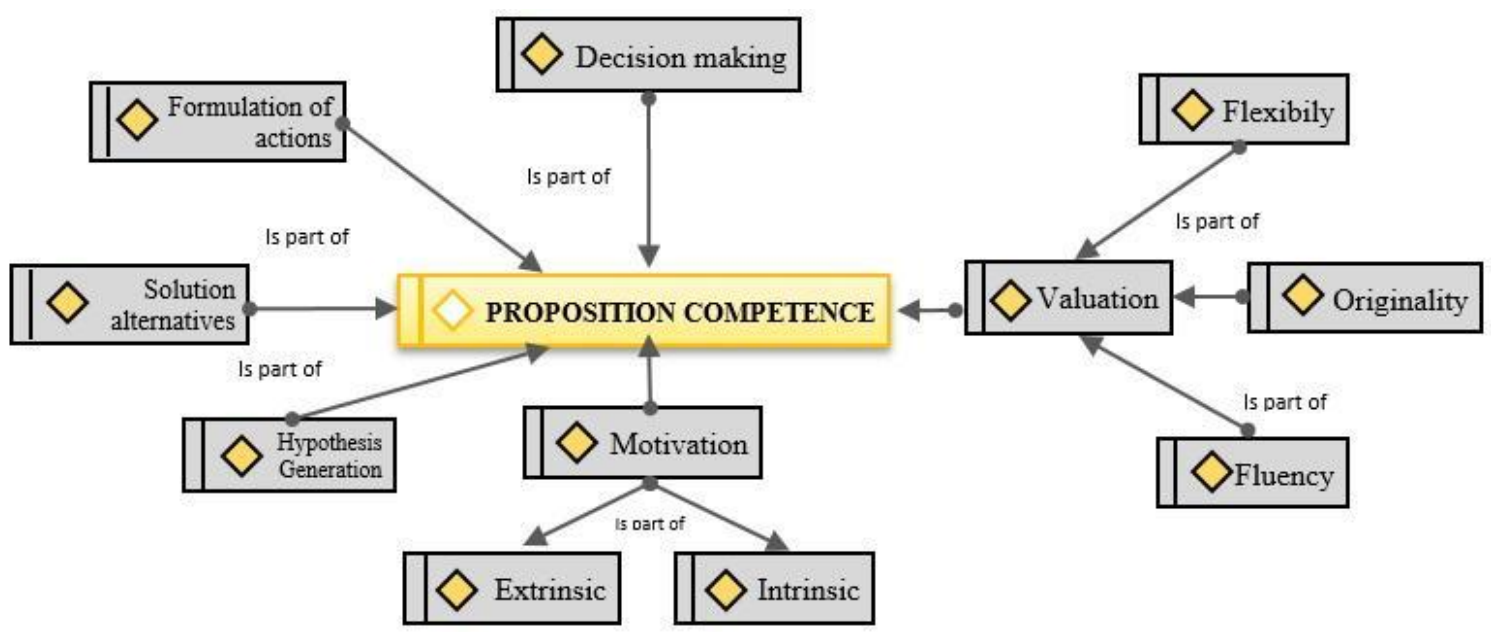

Source: Own elaboration based on the systematization model (Velandia-Mesa et al., 2017)

\section{Conclusions}

Currently, training for educational research and new curricular trends brings renewing and progressive currents that seek to strengthen training dynamics from a permanent reflection of research practice nurturing different fields of action. Accordingly, the training processes for educational research address new challenges that go beyond the methodological aspects and focuses efforts on research ethics, relational skills and communicative, argumentative, technological, critical and proactive skills, in order for intraining teachers to solve problems, which are typical of the educational scenario. Despite the heterogeneity of dynamics in research training, some practices that blur the real objective of research as a source of collective contribution and problem solving are still rooted.

In spite of the fact that favorable actions have been taken in the training of researchers, there are still elements that become obstacles to research-service and production of educational research. This issue is explained by considering the strong influence of theory in the research processes, the gradual devaluation of the educational experience as an agent in the construction of knowledge, the pedagogical practice focused on instrumentalization, and the ignorance towards the impact of training for research and the disjointed reasoning of actions, that is, the objectives of TER detached from reality.

Although the graduation project is an approach to student performance, it is essential to include it in the evaluation and learning outcomes based on research competencies throughout the training process and the development of research projects. This implies 
strengthening the assistance, follow-up and mentoring of the training processes for research, which entail, above all, the construction of ethical actions and behaviors, framed in responsible acts. Likewise, in the context of occurrence, the need to strengthen relational and proactive competence was observed, linked to teamwork and conflict resolution.

The reconfiguration of research competencies implies the development of training research processes by taking into account the dimensions of knowledge, doing and being. This statement leads to the reflection regarding the processes of evaluation in the training in educational research (validation of scales of assessment), which are related to the development of theory-practice, the production of knowledge, and the development of research-service.

TER is a main character in the current dynamics of a globalized world, since professionally qualified people are required, who not only cultivate knowledge, but assimilate permanent transformations considering the accelerated rhythm at which society advances. Based on these dynamics, TER based on problem solving, reflection and systematization is proposed which ensures the capacity of relearning, ethical and multidisciplinary work, through the application of knowledge in real situations and in different environments, to approach the understanding and identification of phenomena, appropriating learning from action and behavior.

To progressively reach higher levels of maturity in the processes of research training, it is required that teachers-researchers and the educational practices in the academic curriculum focus on the development of new competencies models that lead educational research to entrepreneurship, service, interdisciplinary work and innovation in academic settings. If the implementation of research competencies models focused on instruction continues, the gap between operability and the decision-making to transform educational scenarios will widen.

\section{Acknowledgements}

This work has received support from Universidad El Bosque (Bogotá, Colombia); the Vice-President for Research and the Faculty of Education in the Early Childhood Education program in which the Department of Research Methods and Diagnosis in Education of the University of Murcia (Spain) collaborates, through its Doctoral Program in Education of the International Doctorate School; and the Education and Research UNBOSQUE Colciencias research group. 


\section{References}

Agencia Nacional de Evaluación de la Calidad y la Acreditación [ANECA]. (2013). Guía para la redacción, puesta en práctica y evaluación de los resultados del aprendizaje. Madrid: Cyan. Recuperado de http://www.aneca.es/Sala-de-prensa/Noticias/2013/ANECApresenta-la-Guia-para-la-redaccion-y-evaluacion-de-los-resultados-del-aprendizaje

Alfaro, Grettel. y Alvarado, Silvia. (2018). El Perfil de profesores universitarios de universidades públicas y privadas en la carrera de Educación. Actualidades Investigativas en Educación, 18(2), 1-21. Doi https://doi.org/10.15517/aie.v18i2.33161

Avendaño-Castro, William., Rueda-Vera, Gerson. y Paz-Montes, Luisa. (2016). La investigación formativa en las prácticas docentes de los profesores de un programa de contaduría pública. Cuadernos de Contabilidad, 17(43), 157-182, doi: 10.11144/Javeriana.cc17-43.ifpd

Ayala Carabajo, Raquel. (2016). Formación de investigadores de las ciencias sociales y humanas en el enfoque fenomenológico hermenéutico (de van Manen) en el contexto hispanoamericano. Educación XX1, 19(2), 359-381, doi: https://doi.org/10.5944/educxx1.16471

Baker, David P., Day, Rachel and Salas, Eduardo. (2006), Teamwork as an Essential Component of High-Reliability Organizations. Health Services Research, 41(4p2), 1576-1598, doi: 10.1111/j.1475-6773.2006.00566.x

Baños Vila, Ruth., Rubio Hurtado, José. y Berlanga Silvente, Vanesa. (2014). La investigación formativa a través del aprendizaje orientado a proyectos: una propuesta de innovación en el Grado de Pedagogía. Innovación Educativa, (24), 241-258, doi: 10.15304/ie.24.1586.

Barnett, Ronald. (2008). Para una transformación de la Universidad. El saber y el vínculo entre la investigación y la docencia. Nuevas Relaciones entre Investigación, saber y docencia. España: Octaedro.

Bautista Correa, Jorge. (2009). Medición de las competencias investigativas en docentes de fisiología: una aproximación empírica. Revista de la Facultad de Medicina, 57(3), 205217, doi: $10.15446 /$ revfacmed

Biesta, Gert. (2007). Bridging the gap between educational research and educational practice: The need for critical distance. Educational Research and Evaluation: An International Journal on Theory and Practice, 13(3), 295-301, doi: $10.1080 / 13803610701640227$

Botella, Juan. y Zamora, Ángela. (2017). El meta-análisis: una metodología para la investigación en Educación [Meta-analysis: a methodology for research in education]. Educación XX1, 20(2), 17-38, doi: 10.5944/educXX1.18241

Bravo Salinas, Nestor. (2007). Competencias proyecto Tuning-Europa, Tuning-América Latina. México: Centro Comunitario de Aprendizaje. Recuperado de 
http://www.cca.org.mx/profesores/cursos/hmfbcp ut/pdfs/m1/competencias proyectotu $\underline{\text { ning.pdf }}$

Campos Céspedes, Jensy. y Chinchilla Jiménez, Alexis. (2009). Reflexiones acerca de los desafíos en la formación de competencias para la investigación en educación superior. Revista Actualidades Investigativas en Educación, 9(2), 1-20. DOI 10.15517/aie.v9i2.9525

Chacón Pinilla, Ruth. (2014). Del maestro como investigador: ¿reto y necesidad? Itinerario Educativo, (64), 249-257, doi: 10.21500/01212753.1430

Chaves Salas, Ana., Kunze, Ingrid., Müller-Using, Susane. y Yoshiro, Nakamura. (2017). ¿Cómo forman al profesorado en Educación Secundaria en Alemania? Actualidades Investigativas en Educación, 17(3), doi: 10.15517/AIE.V17I3.30106

Clavijo Gallego, María. (2014). Introspección desde la formación para la investigación y la investigación formativa. Praxis y Saber, 5(10), 93-119, doi: 10.19053/22160159.3024

Consejo Nacional de Acreditación [CNA], (2013). Lineamientos para la acreditación de programas de Pregrado. Bogotá: CNA. Recuperado de https://www.mineducacion.gov.co/1759/articles-341938 archivo pdf.pdf

Creswell, John. (2013). Research design: Qualitative, quantitative, and mixed methods approaches. Sage publications.

Delgado Camacho, Clemencia., Guzmán, María. y Mora Ramírez, Ángela. (2009). La pedagogía y la investigación formativa en el Politécnico Grancolombiano. Poliantea, 5(1), 27-43, doi: 10.15765/plnt.v5i8.284

Dewey, John. (1937). Experiencia y educación. Buenos Aires: Losada.

Díaz-Barriga, Ángel. (2011). Competencias en educación: Corrientes de pensamiento e implicaciones para el currículo y el trabajo en el aula. Revista iberoamericana de educación superior, 2(5), 3-24, doi: 10.22201/iisue.20072872e.2011.5.61

Durán-Bellonch, Mar. e Ion, Georgeta. (2014). Investigadoras con éxito en la universidad... ¿Cómo lo han logrado? Educación XX1, 17(1), 39-58, doi: 10.5944/educxx1.17.1.10704.

Elliott, John. and Adelman, Carol. (1984). Reflecting where the action is: The design of the Ford Teaching Project. En Christine O`Hanlon (ed.), Professional development through action research in educational settings (pp. 7-18). London: Falmer Press.

García Bejarano, Alicia., Angarita, Janeth. y Velandia Mesa, Cristian. (2013). Implicaciones pedagógicas del uso de las TICs en la educación superior. Revista de Tecnología, 12(3), 36-56.

Gimeno, José. (1984). El profesor como investigador en el aula: un paradigma de formación de profesores. Educación y sociedad, 2, 51-73. 
Hernández Sampieri, Roberto., Fernández Collado, Carlos., y Baptista Lucio, Pilar. (2010). Metodología de la investigación. México: McGraw-Hill.

Herrera González, José. (2012). La formación de docentes investigadores: el estatuto científico de la investigación pedagógica. Magis. Revista Internacional de Investigación en Educación, 3(5), Recuperado de https://revistas.javeriana.edu.co/index.php/MAGIS/article/view/3526

Kennedy, Mary. (1997). The connection between research and practice. Educational Researcher, 26(7), 4-12 doi: 10.3102/0013189X026007004

Lavis, John., Robertson, Dave., Woodside, Jennifer., McLeod, Christopher. and Abelson, Julia. (2003). How can research organizations more effectively transfer research knowledge to decision makers? Milbank Quarterly, 81(2), 221-248, doi: 10.1111/14680009.t01-1-00052

León Acosta, Jennifer., Vallejo Ovalle, Catalina., Parra Carrasquilla, Adriana. y Obregoso Rodríguez, Yolima. (2010). Clasificación múltiple de ítems y las representaciones sociales sobre ambiente en profesores rurales. Actualidades Investigativas en Educación, 10(2), doi: 10.15517/aie.v10i2.10112

Longi Pedraza, Jorge (2018). Experiencias de formación como investigadores educativos de estudiantes de un programa de doctorado en educación. Actualidades Investigativas en Educación, 18(2), 1-33. Doi https://doi.org/10.15517/aie.v18i2.33134

Mayorga-Fernández, José., Madrid-Vivar, Dolores. y Padial-Díaz, Salvador. (2016). Mercado de trabajo versus formación inicial: competencias del pedagogo en el TFG. Revista Brasileira de Orientação Profissional, 17(2), 125-137. Recuperado de https://www.redalyc.org/jatsRepo/2030/203051246002/html/index.html

Mortimore, Peter. (2000). Does educational research matter? British Educational Research Journal, 26(1), 5-24, doi: 10.1080/014119200109480

Murillo, Javier. y Perines, Haylen. (2017). Cómo los docentes no universitarios perciben la investigación educativa. Revista Complutense de Educación, 28(1), 81-99, doi: https://doi.org/10.5209/rev RCED.2017.v28.n1.48800

Pacheco, Javier. (2010). La clasificación múltiple de ítems y el análisis de escalogramas multidimensionales. Revista Suma Psicológica, 3(1), 25-37.

Páramo, Pablo. (2018). La investigación en ciencias sociales: Técnicas de Recolección de Información. Bogotá: U. Piloto de Colombia.

Paul, Richard. y Elder, Linda. (2005). Estándares de competencia para el pensamiento crítico. Estándares, Principios, Desempeño, Indicadores y Resultados. Recuperado de https://www.criticalthinking.org/resources/PDF/SP-Comp Standards.pdf 
Pérez Rocha, María. (2012). Fortalecimiento de las competencias investigativas en el contexto de la educación superior en Colombia. Revista de investigaciones UNAD, 11(1), 9-34, doi: 10.22490/25391887.770

Porlán, Rafael. (1988). El maestro como investigador en el aula. Investigar para conocer, conocer para enseñar. Revista Investigación en la escuela, (1), 63-69. Recuperado de https://idus.us.es/xmlui/handle/11441/59047

Rodríguez Bello, Luisa. (2004). El modelo argumentativo de Toulmin en la escritura de artículos de investigación educativa. Revista Digital Universitaria, 5(1). 1-18. Recuperado de http://www.revista.unam.mx/vol.5/num1/art2/ene art2.pdf

Stenhouse, Lawrence. (1998). La investigación como base de la enseñanza. Madrid: Ediciones Morata.

Tejada Fernández, José. y Ruiz Bueno, Carmen. (2016). Evaluación de competencias profesionales en Educación Superior: Retos e implicaciones. [Evaluation of professional competences in Higher Education: Challenges and implications]. Educación XX1, 19(1), 17-38, doi:10.5944/educXX1.12175

Tirado, Luis. Estrada, Jairo., Ortiz, Raúl., Solano, Hernando., Restrepo, Guillermo., Alfonso, Diego., Delgado, Juan. y Ortiz, Delfín. (2006). Competencias profesionales: una estrategia para el desempeño exitoso de los ingenieros industriales. Revista Educación en Ingeniería, 1(1), 1-11, doi: 10.26507/rei.v1n1.26

Torrelles Nadal, Cristina., Coiduras Rodríguez, Jordi., Isus, Sofìa., Carrera, Xaxier., París Mañas, Georgina. y Cela, José. (2011). Competencia de trabajo en equipo: definición y categorización. Profesorado: revista de currículum y formación del profesorado, 15(3), 329-344.

Toulmin, Sthepen. (2003). The uses of argument. California: Cambridge university press.

Velandia, Cristian., Pastor, Francisca. y Segura, María. (2018). La formación para la investigación educativa en ambientes ubicuos de aprendizaje. Debates en Evaluación y Currículum, 4(4). Recuperado de: https://goo.gl/Vo2nxM

Velandia-Mesa, Cristian., Serrano-Pastor, Francisca. y Martínez-Segura, María. (2017). La investigación formativa en ambientes ubicuos y virtuales en Educación Superior. Comunicar: Revista Científica de Comunicación y Educación, 25(51), 09-18, doi: 10.3916/C51-2017-01 
Revista indizada en
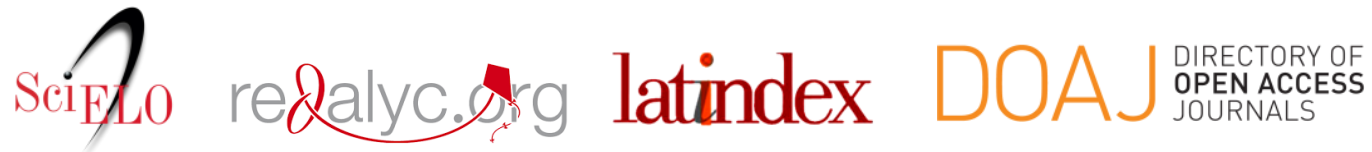

Distribuida en las bases de datos:

๑ Dialnet

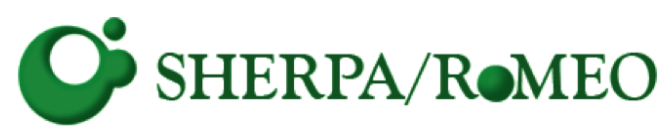

REDIB

Red Iberoamericana

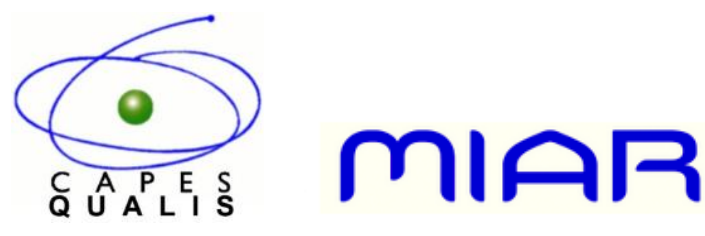

